\title{
Scattered Limbs: fragments for a history of medicine
}

\section{Anecdotes}

Like literature, medicine started out as an oral history and became so comprehensively a written one that it is easy to forget where it came from. In fact, it is made up of a myriad of oral histories anecdotes. For most of their university training medical students are so immersed in the great master narratives of disease recognition and the burning issues of public health that it seems almost comic to be faced with a patient at all. Indeed, it is only relatively recently in the history of medical teaching that students have been taken systematically to patients' bedsides to learn about the natural history of disease, and even now teaching in some continental European countries still runs shy of the body - semiological findings are important, but only if they can be abstracted from patients. The problem with patients is that they like to talk, and some even like to talk back.

Anecdotes (literally 'items that have not been published' or 'secret histories'), have a rather dismissed existence in literature, even though one of the great works of English literature, John Aubrey's Brief Lives is appreciatively full of them. ${ }^{1}$ Most of Aubrey's anecdotes are free-standing exempla of his chosen lives. The 6thcentury historian Procopius used them to hint at the true story of the seamy goingson at the court of Justinian - his anecdotes are stories that debunk the glorious official history. And Stendhal's journeys through France and Italy are full of loosely structured anecdotes, as he struggled to reveal the mishaps that befall his characters on account of a flaw in their understanding of themselves. Nothing points up the difference between the ideal and the real like the well-chosen anecdote.

As with anything meaningful which stands at the intersection of two ways of understanding the world, or between public chronicles and private passions, anecdotes have a trickster quality to them. They can be very conventional, upholders of the world order just the way it is (moralising newspaper items and factoids), and deeply subversive accounts of odd events for which the established view of history and perhaps even human nature has no response. They find no echo in the vast archives of knowledge.

And while they might be secret histories, they never add up to a comprehensive 'secret history': anecdotes are contingent reminders that we are unable to ever fully understand the hidden workings of anything, from the market to God.

In their most subtle form, anecdotes reveal both the forgotten connections that have to be re-established in order to make sense of the past, and the variety, excluding all unity, of that past.

\section{The confidence of medical men at the beginning of the 20th century}

Chekhov (pictured below) helped to prevent a Russian journal of surgery The Surgical Chronicle from going under in 1895, fought 'the Indian commas' (cholera vibrio), cleaned up the hovels in Talesh, Novosyolki, and Melikhova, and ensured the provision of clean water on his estate, under the force of the conviction that while nature is not benevolent, one could take comfort, much as Thomas Hardy did, from human agency and creatureliness 'loving-kindness, operating through scientific knowledge.'

John Coope, Doctor Chekhov: A Study in Literature and Medicine, Cross Publishing 1997.

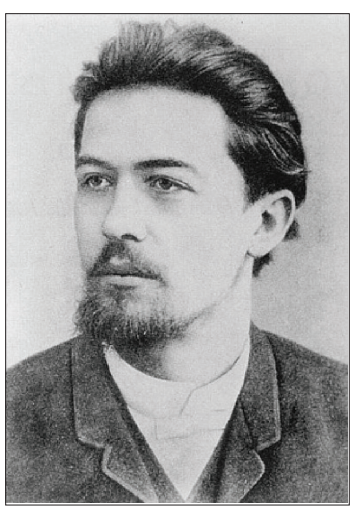

\section{The historian}

In his memoir A Sense of Place, the historian Richard Cobb recalls his favourite uncle, a country doctor who often took him along on rounds: 'He was a tremendous gossip, and endlessly inquisitive about people; indeed, I think he only practised medicine in order to get into other people's houses. I would sit waiting in the car while he did the rounds, and, after each visit, he would come to the car triumphantly with some new item of malice, rather like a researcher after a good day in the Archives Nationales.'

This desire to read other people's letters, to enter the inner sanctum of other people's homes, stayed with Cobb all his life: it is what he claims 'being, or becoming, a historian is all about'. In a sense, the historian's task is weightier than the doctor's. He has to truffle the records for the untold anecdote, for what has eluded memory and recollection and treat testimony like a disbeliever. Then he has to sentence people to life.

Richard Cobb (1917-1996): Professor of Modern History at Oxford and one of the best writers about the French: A Sense of Place. London: Duckworth, 1975.

\section{Sick-lit}

A subgenre to be avoided unless you want to succumb to toxic empathy.

Antidote: one chapter omni nocte of François Rabelais' The Lives, Heroick Deeds, and Sayings of Gargantua and Pantagruel in the magnificent 1653 translation by Sir Thomas Urquhart, Everyman's Library, New York, 1994.

\section{Marxists and the market}

The last decade has seen the appearance of a number of books criticising what has been called therapy culture, barely noticed against the hundreds of books insisting, on the other hand, that illness is an unique learning experience. What's intriguing about this critical trend - certainly more of an intellectual than a popular movement is that many of its leading theorists are former Marxists, chief among them Frank 
Furedi, professor of sociology at the University of Kent and former chairman of the Revolutionary Communist Party. They observe that therapy culture has replaced religion as the opium of the people, illness has become a first-order experience and health comprehensively politicised; and that consequently we have entered a kind of arms race of public emoting. None of these are false observations; yet the suspicion remains that critics of such stripe are motivated by ideological reasons and less by an old-fashioned desire to recover the fortitude that marked an earlier generation. Their philosophy of unlimited progress seems as misplaced as that of those who aspire to victim status. If only the people weren't so narcotised by health and actually got around to overthrowing the state!

Is self-deification the way forward? Only Spiked Magazine knows:

http://www.spiked-online.com

\section{Li medici me crearono e distrussono}

In a pun scribbled in his notebook on his patron Lorenzo Medici and the medical profession (I medici), Leonardo da Vinci became one of the first thinkers to advance the understanding - later associated with Faust and thereafter with the economist Schumpeter - that creativity and destruction are intimate allies. In Leonardo's eyes physicians practised a killing and not a healing art since they preyed on infirmities and ailments.

Review of Prophet of Innovation: Joseph Schumpeter and Creative Destruction, Harvard UP, 2007, by J. Bradford DeLong:

http://chronicle.com/free/v54/i15/15b00801.htm

\section{The body of power}

Most of the comments on the film adaptation of Giles Foden's novel The Last King of Scotland see it as a straightforward moral tale about what happens when a politically naive but energetic young Scottish doctor, Nicholas Garrigan, doing medical relief work in a bush hospital in Uganda, encounters the head of state, Idi Amin, in person - that is His Excellency President for Life Field Marshall Al Hadj Doctor Idi Amin Dada, VC, DSO, MC, Lord of All the Beasts of the Earth and Fishes of the Sea and Conqueror of the British Empire in Africa in General and Uganda in Particular. Impressed by the young doctor's practical approach to immediate trauma care, and long an admirer of Scottish (military) traditions, Amin invites him to become his personal physician in Kampala. At first things go swimmingly well, but little by little even the self-absorbed Garrigan (the novel is based on a real-life soldier who became Amin's closest adviser) has to face up to the fact that the hypochondriac whose petty illnesses he gets up to treat in the night is also a tyrant with a penchant for the most ridiculous and outrageously brutal whims. But the doctor gets off on the thrill of danger: he even has an adulterous affair with the dictator's third and youngest wife, a tryst which gets her butchered and almost costs him his own life.

It would be wrong to assume that it is pure naivety which drives this young doctor close to the heart of darkness. Historically, physicians reached the apex of power by ruling over the body of power itself. This becomes clear in the film when Garrigan expeditiously relieves Amin of abdominal cramp during a severe bout of flatulence and for the first time senses the physical danger he has placed himself in: he has ridiculed - albeit inadvertently the royal body. Those who heal princes and potentates are bound to be raised into relationships of power themselves, just as they can be cast down with them. But it is still not enough to make the selfinvolved Garrigan aware of his own moral temporising. 'I heard him calling himself the last rightful king of Scotland again on the radio,' writes Garrigan in the novel, 'I thought, in a wild moment, that it had some special relevance for me. As if I were his subject.' Which, of course, is precisely what he is. Amin is astute enough to make the fey Garrigan his factotum, and give him the ministerial task (for which he has absolutely no qualifications) of overseeing the architectural designs of a conference hall for the next Pan-African Congress.

Things go horribly wrong in Uganda, and Garrigan is lucky to escape with his life. But he is so smugly self-absorbed that the film ends on an uncomfortable note: just how does a doctor manage to tend such atrocious hurts and wounds without suffering some kind of ricochet himself?

Foden's first novel is a variant on a type familiar during the high imperial era: one in which a young man both proves and improves himself by 'going out' to Africa or India. His fictional hero has a little in common with John Buchan's David Crawfurd who, in Prester John, ${ }^{2}$ set in the immediate aftermath of the Anglo-Boer War, engages on a process of discovery, learning, and maturation, eventually escaping at improbable odds from a situation that threatens the empire itself. Initially considered a boys' adventure story Prester John has since grown up, now being considered in the same breath as Buchan's other novels. Post-colonialism still offers lots of scope for self-absorbed young innocents in search of adventure: they merely have to flag their humanitarian credentials and one day, if they're lucky, they might just end up being Foreign Minister - of their own probably irrelevant kingdom.

Giles Foden, The Last King of Scotland. London: Faber \& Faber, 1998.

\section{Physician, heal thyself}

It sounds like a taunt, but Jesus's famous saying was part of a longer sentence addressed to the people of his home town Nazareth - 'Ye will surely say unto me this proverb: Physician, heal thyself.' (Luke 4; 23). Cyril of Alexandria even calls it a 'witticism', and states that it was a common saying among the Jews of the time. The Nazareans wanted to know why this man who was being acclaimed in the region as the Messiah could perform miracles in the neighbouring town of Capernaum but not in Nazareth, where he was merely Joseph the carpenter's boy. Until only a short time before, he had been a carpenter himself. Jesus is saying that they will tell him to save his reputation by proving what he says is true, the implication being that he first has to cast out his own demons before he can presume to cast out other people's. Not having any demons, he refuses to oblige; and he tells them that prophets are never recognised by people who have known them with a snotty nose and schoolbag: 'Verily I say to you, that no prophet is acceptable in his own country.' After general uproar, they decide to 
throw him off the hilltop on which Nazareth is built, but being a carpenter he must have cut a hole in the floor and disappeared, as it says in the Good Book, 'through their midst'.

On the meaning of the Gospel parables:

http://www.orthodoxphotos.com/readings/parables

\section{Joining the right guild}

To make himself eligible for election to public office in his natal city at the end of the 13th century, Dante, as a member of the minor aristocracy had to join one of Florence's trade guilds. He chose to enrol his name among those of the Guild of Physicians and Apothecaries, a trade guild which also happened to incorporate the Papermakers.

More, infinitely more about Dante and the subtleties of the Divine Comedy at:

http://danteworlds.laits.utexas.edu

\section{Work and leisure}

The French suspicion of British general practice and its state-controlled status stems from a vestigial remembrance of what the expression ars liberalis entails: liberal practice is work that is meaningful in itself. British doctors, in their eyes, abandoned this historical form of guild practice and opted for the artes serviles; that is, chose to work in a way which, in the older sense of the term, is utilitarian: servile work is always work for a purpose. It makes an idol of the social. But the French are surely the more deceived. For doctors in both countries have, since the end of World War II been working within the framework of a state-controlled social security system. And the concept of a human activity which is meaningful in itself died a long time ago, or became as quaint as writing poetry. For modern people even leisure has to be dedicated to something meaningful in itself. That is why adjective 'otiose', which derives from the Latin word otiosus, meaning leisure, has acquired a pejorative slant in English.

Josef Pieper: Leisure, the Basis of Culture. Indiana: St. Augustine's Press, 1998.

\section{Sacred vegetables}

Vincent van Gogh painted Still Life with a Plate of Onions (shown above) in January 1889 , shortly after returning to the 'yellow house' on the Place Lamartine, Arles. He

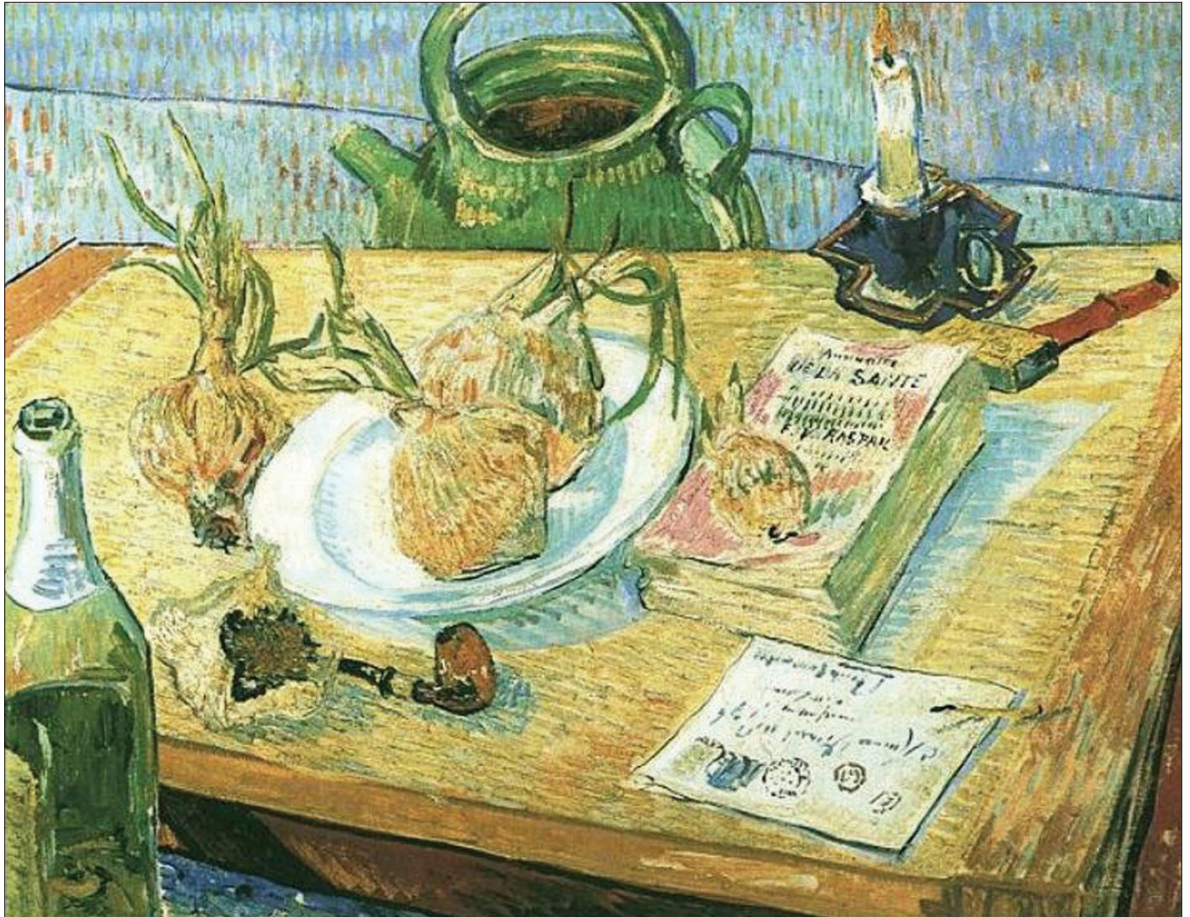

had been admitted to hospital just before Christmas in a critical state: having first threatened his friend Paul Gauguin with a razor he had lopped off the lower part of his own left ear. The still life (of which he painted 194 in his career) shows his drawing board on a trestle between a bottle of white wine and a large green jug. According to Guy Davenport, ${ }^{3}$ who has also written about this painting, its visual force attaches to 'an utterly primitive and archaic feeling that a picture of food has some sustenance.' Nature is a dead language that needs a painter to bring it to life. Variously arranged on the board are a pipe and shag tobacco in paper wrap, a bowl with white onions, a candlestick and candle, a matchbox, sealing wax, a franked registered letter, upside-down in relation to the viewer, and a thick buff-coloured book. It is just possible to make out the title on the book: Manuel annuaire de la Santé par Frédéric-Vincent Raspail. This was a hugely popular work, first published in 1845, whose full title reveals its purpose: it was a household pharmacy guide 'containing all the theoretical and practical information' that would allow readers to prepare medications for their own use.

François Vincent Raspail was, like 'I'pasteur Vincent', an instinctive, rather literal-minded democrat, who studied grasses because of 'their humble, 'proletarian' place in the kingdom of nature.' ${ }^{4} \mathrm{He}$ believed in the healing properties of camphor, and his advocacy is largely responsible for its extensive use in the 19th century. But the volatile oils of Allium cepa have been used for much longer as a curative: I remember sitting up in amazement when my wife chopped up an onion, wrapped it in muslin and heated it gently in the microwave before wrapping it around our children's ears when they were suffering - as do so many small children because of their slightly different morphology of the ear in childhood - from glue ear; the room smelt awful but by the morning their pain had gone. This homemade poultice would have been familiar to Hippocrates, who used syrup of onion as an expectorant and diuretic.

Vincent van Gogh didn't need onions to make himself weep; he wanted them to cure him of his torments, though they certainly wouldn't restore his amputated earlobe. And the following century discovered that onions, skinned and cut, could cover up the smell of the dead, as Günter Grass tells us in his controversial autobiography Peeling the Onion.

Still Life: Drawing Board, Pipe, Onions and Sealing Wax (oil on canvas) hangs in the Rijksmuseum Kröller-Müller, Otterlo, the Netherlands, which has the second-largest collection of Van Gogh's paintings in the world. 


\section{The cult of vestiges}

The Journal of Pineal Research is a reputable scientific monthly that brings together research on the organ Descartes believed to be the seat of the soul. This tiny $(8 \mathrm{~mm})$ pine-cone-shaped structure at the base of the two hemispheres is of course of considerably greater importance in vertebrate mammals other than humans: in rodents, for example, it is purely endocrine and lacks neurons. But it does secrete melatonin and seems to have a role in delaying sexual maturation. Because of the strong similarity between the pinealocytes and the photoreceptor cells of the eye, some evolutionists believe it to be implicated in the cycle of circadian rhythms; Madame Blavatsky considered it the mystical third-eye; and Georges Bataille - not to be outdone - the blackbox of Western rationality.

\section{The Journal of Pineal Research:}

http://www.blackwellpublishing.com/journal.asp ?ref $=0742-3098$

\section{Being bad to patients}

'Humanity is overrated,' quips Dr Greg House, in one of the most popular doctor series on the box. It's not grand issues of life and death which carry this series, but the cane-wielding $\mathrm{Dr}$ House (Hugh Laurie), who manages to get away with being both misanthrope and junkie (his drug of choice is Vicodin, a semisynthetic morphine derivative) by virtue of his ability to solve diagnostic dilemmas that would have stumped the combined acumen of $\mathrm{Dr}$ Watson and Sherlock Holmes. The drama's screenwriters have recognised that by bestowing more than the usual quota of negativity on House (pictured below), they can make his character all the more commanding: his abrasive, odiously intelligent, often malicious personality is accepted by the sick as a benefit. And the 'unity of

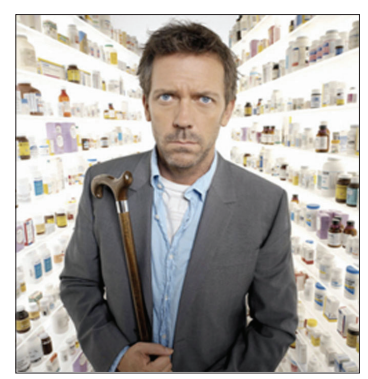

opposites' gets seen from a new standpoint. And the viewer becomes the addict.

Another quip from House: 'Patients sometimes get better. You have no idea why, but unless you give a reason they won't pay you.' The writers of the series are evidently well-read, since we find Heraclitus ${ }^{5}$ expressing a similar sentiment about the role of money in medicine: 'Having cut, burned and poisoned the sick, the doctor then submits his bill.' The issue of being paid for services to humanity is likely to remain an unresolved one, however - to the despair of the managers in the one hospital that is prepared to employ him - House regularly fails to submit his bills.

When have we ever seen a doctor treat his patients as an inconvenience, if not a downright waste of time, regarding them with the eye of Sun Tzu, in his 2500 yearold treatise The Art of War?' (House can read Mandarin, as well as Hindi and Spanish.) Here is the extraterrestrial looking down on humanity as so many bad actors. 'The ill person is the tactical, the illness the strategic object of medicine.' It was the German soldier and writer Ernst Jünger who wrote that, but it is the kind of thought that Dr House, were he less busy visiting $X$ rated websites, might have scribbled on the back of a prescription pad.

Everything you might ever need to know about Gregory House, M.D., including his contribution to the recent popularity of the word 'curmudgeon':

http://en.wikipedia.org/wiki/Dr._Gregory_House

\section{Pre-Victorian values}

Virtue as expressed by compassion, benevolence and sympathy was always more important, as Gertrude Himmelfarb has shown, in Britain's Enlightenment than in France's: the liking for 'enlightened despotism' among the philosophes was predicated on their disdain for the canaille (injudicious use of which word - riff-raff or scum - got Nicolas Sarkozy into trouble a few years ago), whereas the British, though frightened at times by their own mobs, as in Hogarth, genuinely believed in a common fund of moral and social obligations.

To find out why the word 'Enlightenment' only entered the English language in 1910 read

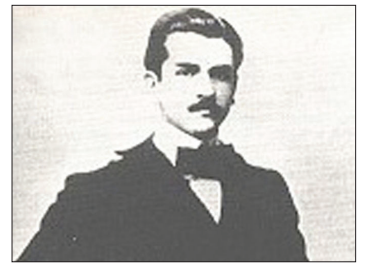

Lara Feigel's review of Gertrude Himmelfarb, The Roads to Modernity. London: Vintage, 2006:

http://www.guardian.co.uk/books/2008/mar/09/ politics.society

\section{The makings of a cult author}

After the death of his elder brother Georges, the fond, wealthy, and overbearing mother of Raymond Roussel (1877-1933; pictured above) - unnoticed in his lifetime except for his bizarerries and extravagantly costly self-productions insisted that her third son should, according to his biographer Mark Ford, 'undergo a medical examination every day. ${ }^{7}$ Perhaps it is not altogether surprising then that when Big Mother accompanied her son on a tour of India and Ceylon in 1910, she ensured a coffin was brought along for the voyage so as not to importune the other travellers in the event of her demise. Perhaps what is difficult to understand is why she should want to distance herself in the first place from the ministrations of the medical profession. She could have afforded to take a doctor along instead of her son.

Website (in French) dedicated to books and images of Raymond Roussel:

http://livres.fluctuat.net/raymond-roussel.html

\section{Institutionalising altruism}

Kenneth Minogue ${ }^{8}$ comments wryly on the kind of internationalism which flourished after the defeat of the Nazis, that 'no question arose of a monastic or ascetic idealism being required of those who worked for the betterment of mankind.' All too true: WHO was lavishly resourced in the beginning, and since its universality was subject to the principle of equal distribution of posts among member states it became a matter of prestige for the leading doctors of the most obscure countries to secure an appointment at the global institute for the administration of pity. But ever since its foundation, the resources have dwindled and dwindled. 
The website of the World Health Organization is available in English, French, Spanish, Russian, Mandarin, and Arabic at:

http://www.who.int/en

\section{The mystery of a life}

There is an astonishing sense in early Romantic poetry of people noticing each other for the first time, of being wholly absorbed by another's life - or at least writing about it. John Keats, ${ }^{9}$ in a journal letter to his brother George, wrote:

'A Man's life of any worth is a continual allegory - and very few eyes can see the Mystery of his life ...'

However, it was William Wordsworth who gave more memorable form to this consideration in his poem about the leech gatherer who met with his sister Dorothy on the road to Carlisle. This destitute old man bent almost double impressed the Wordsworths with his dignity, composure, and measured Scotch speech. The poet, who confesses that he has lived his whole life 'in pleasant thought/as if life's business were a summer mood', is moved by this archaic figure, 'not all alive nor dead': he sees him first as a dream messenger, then 'like a man from some far region sent/ To give me human strength by apt admonishment.' It is another kind of admonishment to realise that this old man, who could no longer eke a trade because of the diminishing numbers of Hirudo medicinalis in the Lake District, sold the leeches that he caught to the members of the medical profession. (Dorothy recorded his words in her diary for October 3, 1800):

'He said leeches were very scarce partly owing to this dry season, but many years they have been scarce ... Leeches were formerly 2/6 [per] 100; they are now 30/.'

Doctors, like poets, are singularly placed to observe the indefatigable and sometimes poignant capacity of people to endure; and by observing this capacity in others are themselves helped to endure.

Read The Leech-Gatherer, or Resolution and Independence at:

http://www.readprint.com/work-1557/WilliamWordsworth

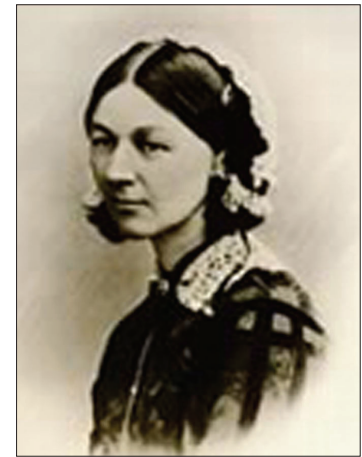

\section{A nursing icon}

One of the interesting aspects of Mark Bostridge's biography of Florence Nightingale (pictured above) is the way it places her as an explicitly Protestant reformer in a society where the work of caring, lay and religious, was still associated with the charitable work of Catholic societies. The outcry about the death-rates among the soldiers placed in the military hospitals of the Crimea gave Anglican sisterhoods the opportunity to enter public life without arousing the slightest suspicion about their religious affiliations or even patriotism. But some nurses went out to the Crimea as ladies and some as women, the latter even being expected to undertake the heavier, more menial and unpleasant tasks, and even in some cases to wait on the lady nurses. It was a lady's prerogative to be a manager.

Such were the problems of class in Victorian Britain: philanthropy was by definition what a lady of better class provided to her social inferiors. What was a nurse to do, when she couldn't select her patients or, even worse, the male doctor from whom she would take her orders turned out, despite all the endeavours of the entire profession to be taken in through the front door and not the servants' entrance, to be a social inferior? It took Florence Nightingale a decade to convince her family to allow her to accept the post of Superintendent of the Establishment for Gentlewomen During Illness in Harley Street. And Nightingale failed to further her own cause: by insisting that her own calling came from God she actually made it more difficult for nurses to hold up their profession as an honest, respectable, and worthy way of making a living, and opposed moves to set up a nurses' association and a system of registration.
Read Gillian Sutherland's TLS review of Mark Bostridge's Florence Nightingale: The Woman and the Legend, Viking, 2008, which starts by mentioning Nightingale's distaste for 'all the ministering angel nonsense':

http://tls.timesonline.co.uk/article/0,,253582652540,00.html

\section{The busy time}

'The busy time' John Keats refers to in one of his letters ${ }^{9}$ appears to be the period between autumn 1816 and spring 1817 in which he was dresser and duty surgeon at Guy's Hospital, while preparing his now famous volume Poems (1817) for the press. Gittings and others seem to think he avoided or cut down duties at the hospital in order to attend to his poetry, but I have no difficulty in believing that an onerous working routine abetted his work on his poems. Energy gives rise to exhilaration gives rise to elation.

Download the free e-book of Poems 1817 by John Keats at Project Gutenberg:

http://www.gutenberg.org/etext/8209

\section{Das Werkzeug}

Das Werkzeug - a polysemous term in 18th-century German. It encompassed everything from tool and instrument to bodily organ and body itself, and is found in all these senses in Novalis. A proper education in those days would see to it that a young man acquired the skills and pleasures of manual craftsmanship before those of poetry.

The first English translation of Novalis's unfinished project for a universal science, Notes for a Romantic Encyclopaedia (Das Allgemeine Brouillon) has just been published by David W. Wood, State University of New York Press, 2007.

\section{The birth of the Buddha}

Aged 29, Prince Siddhartha left the protection of his father's palace in order to meet his subjects. It was the profoundly distressing experience - despite his father's best efforts to remove the sick, aged and suffering from public view - of seeing diseased and dying persons which shocked him into his life of asceticism; and ultimate enlightenment as Buddha. What antidote could right living bring to the dreadful perishability of the flesh? - Selfimmolation of the spirit. 
The Buddha's comprehensive $\mathrm{CV}$ can be consulted at:

http://www.thebigview.com/buddhism/buddhasr esume.html

\section{Unreliable narrators}

The novelist Patrick McGrath, whose father was superintendent of Broadmoor Prison, likes to use doctors as narrators because they provide an almost unquestionable veneer of reliability and authenticity - until it sinks in on the reader that their motives are just as undisclosed, fly-by-night, and threadbare as those of any narrator.

Patrick McGrath's novels are annotated at New York University's Literature, Arts and Medicine database:

http://litmed.med.nyu.edu/People?action=view\& $\mathrm{id}=2749$

\section{How to deal with epidemics}

Now and again society gets visited by the cognitive plague. This compels all citizens, those nodes of sovereign consciousness, to assume that doctors have a hidden agenda because they explicitly cultivate a fiduciary relationship with them as patients, and apply a Cartesian strategy of suspicion. Then they discover that the warm friendly atmosphere they used to cherish no longer exists; and write, like Sheila Hale, ${ }^{10}$ 'the old-fashioned general practitioner, with whom you could have a conversation, is nearly extinct.' There is no escape from this tension though, as Ernest Gellner wrote, 'many are offered on the market.' It is partly born of the shock of discovering that lovelessness has been given the power to define what reality is.

Ernest Gellner once wrote that modern people divide into three groups: Religious Fundamentalists, Cultural Relativists (far and away the most populous), and the mildly paradoxical Enlightenment Puritans (among whom he was happy to place himself). Read more in his essential Conditions of Liberty: Civil Society and its Rivals. London: Penguin, 1996.

\section{Moral hyperinflation}

One day some brilliant young sociologist or medical historian will have a field-day analysing the change of tone in the house organ of the British Medical Association over the 20 years of what have been my rather mixed professional experience of medicine. Serenely confident in the early 1980 s, the BMJ of the 1990s exhibited a new bullish, sometimes hubristic tone; and the editorials and commentaries stacked at the front of the journal were clearly modelled on those of The Economist. But a funny thing had happened to medicine on the way to the marketplace. The great sin was now paternalism. The patient was idealised. And suddenly it became quite common to read personal articles in which doctors donned sackcloth and ashes and confessed their sins in public. Had medical idealism gone to the dogs? No, it was just that doctors had imploded under the strain of being moral paragons.

On virtuous and vicious circles in human affairs:

http://en.wikipedia.org/wiki/Virtuous_circle_and_ vicious_circle

\section{We want ethics and all we have is autonomy}

Robert Musil, scientist and the author of The Man without Qualities; ${ }^{11}$

\section{'[There is] an abiding mis-} communication between the intellect and the soul. We do not have too much intellect and too little soul, but too little intellect in matters of the soul.'

He was recognising that the famous poles of human nature according to Friedrich Nietzsche, the Apolline and the Dionysian drives, were actually moving away from each other, not coming together in a life infused with passion and articulate with reason. All the great German novelists of the Weimar years were obsessed with the traits diagnosed by the sociologist Max Weber as distinctive features of the modern rationalised personality: its partiality for functional as against ascribed status, its restless mobility, its wholesale cosmopolitanism. Charisma had become a way of to inspire conformity. Hermann Broch wrote in his novel The Sleepwalkers: ${ }^{12}$

'No system of values can exist without an irreducible residue of the irrational which preserves the rational itself from a literally suicidal autonomy.'

There was no way back. But what was the way forwards?

Max Weber's seminal essay Science as a Vocation was delivered to the students of Munich university at the close of the First World War:

http://www.ne.jp/asahi/moriyuki/abukuma/webe r/lecture/science_frame.html

\section{An axiom}

It is better to do good than talk about doing good.

Website of the John Macmurray Fellowship: http://johnmacmurray.org/intro.html

\section{lain Bamforth}

\section{REFERENCES}

1. John Aubrey (1626-1697): Brief Lives. David R. Godine, New Hampshire, 1999.

2. Buchan J. Prester John. Harmondsworth: 1910. London: Penguin, 1956.

3. Davenport G. Objects on a table: harmonious disarray in art and literature. Counterpoint: Washington, 1998.

4. Weiner DB. Raspail — scientist and reformer. New York, Columbia University Press, 1968.

5. Kahn CH. The art and thought of Heraclitus. Cambridge: Cambridge University Press, 1979

6. Sun Tzu on the Art of War: the Oldest Military Text in the World. http://www.chinapage.com/sunzie.html (accessed 18 Nov 2008).

7. Ford M. Raymond Roussel and the republic of dreams. Faber: London, 2000.

8. Minogue K. Internationalism as an emerging ideology. http://www.samuelgriffith.org.au/papers/html/volum e4/v4chap6.htm (accessed 18 Nov 2008).

9. John Keats (1795-1821): http://simple.wikiquote.org/wiki/John_Keats (accessed 18 Nov 2008).

10. Hale S. The man who lost his language. London: Penguin, 2002.

11. Musil R. The man without qualities. New York: Random House, 1996.

12. Broch, Hermann. The sleepwalkers. London: Martin Secker, 1932.

DOI: 10.3399/bjgp08X376393 